Jurnal Agro 7(2), 2020

\title{
ANTAGONISM POTENCY OF DARK SEPTATE ENDOPHYTES AGAINST Pyricularia oryzae FOR IMPROVING HEALTH OF RICE PLANTS
}

\section{POTENSI ANTAGONISME DARK SEPTATE ENDOPHYTES TERHADAP Pyricularia oryzae UNTUK PENINGKATAN KESEHATAN TANAMAN PADI}

\author{
Dini Yuliani ${ }^{1^{*}}$, Bonny P.W. Soekarno ${ }^{2}$, Abdul Munif ${ }^{2}$, Surono ${ }^{3}$ \\ ${ }^{1}$ Balai Besar Penelitian Tanaman Padi, JI. Raya IX Sukamandi 41256 Subang \\ ${ }^{2}$ Departemen Proteksi Tanaman, Institut Pertanian Bogor (IPB University) Jalan Meranti \\ Kampus IPB Dramaga Bogor 16680 Jawa Barat \\ ${ }^{3}$ Balai Penelitian Tanah, Jalan Tentara Pelajar Nomor 12 Cimanggu Bogor 16114 Jawa Barat \\ *Corespondence : diniyuliani2010@gmail.com
}

Accepted: $20^{\text {th }}$ September 2020 / Approved: $12^{\text {th }}$ November 2020

\begin{abstract}
Blast disease caused by Pyricularia oryzae $(P o)$ is the main disease affecting rice production. Dark septate endophytes (DSEs) is known to improve plant performance and suppress disease. This study evaluated DSEs antagonism potency against $P$. oryzae in improving the rice plant's health. The research stages consisted of: (1). DSE and Po growth rate; (2). Antagonism of DSEs against $P o$; (3). Chitinase; (4). DSEs Viability; (5). DSEs application to rice seeds in nurseries. The results showed the growth of APDS 3.2 colonies had fulfilled Petri $(\mathrm{d}=9 \mathrm{~cm})$ at three days after incubation (DAI), while 4.1 BTG and TKC 2.2.a at 7 DAI. Po had slow colony growth required 20 DAI. Inhibition of APDS 3.2 against Po was $43.75 \%$, higher than of 4.1 BTG (38.60\%) and of TKC 2.2.a (39.76\%). The rice plants inoculated with APDS 3.2 had a relatively higher at seedling height, root length, wet weight, and dry weight than those inoculated with TKC 2.2.a and 4.1 BTG. The highest DSEs colonization was found in APDS 3.2 at $50.56 \%$, followed by TKC 2.2.a (46.67\%) and 4.1 BTG (40\%). DSEs fungus has the potential to suppress rice blast pathogens by improving the health of rice plants, especially APDS 3.2.
\end{abstract}

Key words: Colonization, Growth Rate, Viability

\begin{abstract}
ABSTRAK
Penyakit blas yang disebabkan oleh Pyricularia oryzae $(P o)$ merupakan penyakit utama yang memengaruhi produksi padi. Dark septate endophyte (DSE) diketahui mampu meningkatkan performa tanaman dan menekan penyakit. Penelitian ini bertujuan untuk mengevaluasi potensi antagonisme DSE terhadap $P$. oryzae dalam meningkatkan kesehatan tanaman padi. Tahapan Penelitian terdiri atas: (1). Kecepatan tumbuh DSE dan Po; (2). Antagonisme DSE terhadap Po; (3). Kitinase; (4). Viabilitas DSE; (5). Aplikasi DSE pada benih padi di persemaian. Hasil penelitian menunjukkan pertumbuhan koloni APDS 3.2 telah memenuhi petri $(\mathrm{d}=9 \mathrm{~cm})$ pada 3 hari setelah inkubasi (HSI), sedangkan 4.1 BTG dan TKC 2.2.a pada 7 HSI. Pertumbuhan koloni Po lambat membutuhkan $20 \mathrm{HSI}$. Penghambatan APDS 3.2 terhadap Po sebesar 43,75\% lebih tinggi dibandingkan 4.1 BTG (38,60\%) maupun TKC 2.2.a (39,76\%). Tanaman padi yang diinokulasi APDS 3.2 memiliki tinggi, panjang akar, bobot basah, dan bobot kering relatif lebih tinggi dibandingkan
\end{abstract} dark Septate endophytes against Pyricularia oryzae for improving health of rice plants. Jurnal Agro, 7(2), 134-147. https://doi.org/10.15575/9589 
yang diinokulasi TKC 2.2.a dan 4.1 BTG. Kolonisasi DSE tertinggi dijumpai pada APDS 3.2 sebesar 50,56\%, diikuti TKC 2.2.a (46,67\%) dan 4.1 BTG (40\%). Cendawan DSE memiliki potensi untuk menekan patogen blas padi dengan cara meningkatkan kesehatan tanaman padi, khususnya APDS 3.2.

Kata kunci: Kecepatan tumbuh, Kolonisasi, Viabilitas

\section{INTRODUCTION}

Blast disease caused by Pyricularia oryzae is one of the main limiting factors affecting rice production in Indonesia (Sudir et al., 2014). The fungus can infect rice plants at various stages of growth, from nurseries to harvest (Hosseini-moghaddam \& Soltani, 2013). Blast disease symptoms are characterized by rhombic spots with pointed tips on the leaves, gray or white center spots with brown leaf edges (Siagian, 2016). The shape and colour of the spots vary depending on environmental conditions, age of the spots, and the degree of resistance of rice varieties (Sesma \& Osbourn, 2004).

Leaf blast disease can develop rapidly and cause necrotic so that the absorption of nutrients and rice plant growth are disrupted, causing death if environmental conditions are conducive to pathogens (Dewi et al., 2013). Meanwhile, infection in the panicle neck can reach the grain, and the seeds will carry the pathogen (Zhang et al., 2014). This condition causes the rice crop failure in the world and especially Indonesia, to be relatively high. The yield loss due to the blast disease epidemic is around $50-90 \%$ in various parts of the world, while in Indonesia, it reaches 61\% (Suganda et al., 2016).

The way to control blast disease still relies on the use of synthetic fungicides. Continuous use of synthetic fungicides can become pollutants for the environment and increase pathogen resistance (Zarandi et al., 2009). Control of this disease has not been optimally successful because $P$. oryzae has cellular development and morphology, which are very adaptive in rice plants to break resistance (Fukuta et al., 2014). P. oryzae are also known to have high genetic diversity, making it difficult to control (Ahn et al., 2000).

Microbial antagonists, as biocontrol agents with competition mechanism, antibiosis, parasitism, or induced resistance, are important in controlling plant diseases (Amaria et al., 2015). The use of antagonistic microbes to increase crop yields and protect crops from pests is a promising approach in modern agricultural systems. Endophytes fungi, including biocontrol agents, can complement or even replace the use of synthetic pesticides. Beside, endophytes fungi have some important mechanisms and their ability to reduce disease incidence (Pandya \& Saraf, 2010).

Endophytic fungi such as dark septate endophytes (DSEs) is an alternative for blast disease control to reduce the impact of synthetic fungicides (Sudha et al., 2016). DSE fungi have the characteristics of melanized hyphae, dark in color, and septated, which show dark pigmentation on agar media and can colonize plant roots inter and intracellularly without causing disease symptoms (Handayani, 2017). DSEs colonizes plant root tissue in the form of septated hyphae and microsclerotial structures. The structure of melanized hyphae and microsclerotia make DSES tolerant to environmental conditions that are less conducive or abiotic stress, such as 
drought or sub-optimal land (Santos et al., 2017).

DSEs is expected to suppress pathogens development, induce resistance, and stimulate plant growth to benefit sustainable agricultural practices. Therefore, the exploration of DSEs, which are the best collections, need to be tested in-vitro in suppressing the development of blast pathogens, inducing resistance, and stimulating the growth of rice plants in the nursery so that the antagonist agents with the best ability to control blast disease are obtained. The study aimed to evaluate the Dark Septate Endophytes, which can suppress the development of Pyricularia oryzae in improving rice plant performance in the nursery.

\section{MATERIALS AND METHODS}

\section{Time and Place of Research}

The research was carried out at the Laboratory of Indonesian Soil Research Institute, the Laboratory of KP Muara Indonesian Center for Rice Research (ICRR), the Laboratory and paranet house of ICABIOGRAD, Bogor. The research was conducted from September 2019 to June 2020.

\section{Preparation of Selected Dark Septate Endophytes Isolates}

The DSE isolates used were the three best isolates collected by the Indonesian Soil Research Institute, namely APDS 3.2, 4.1. BTG, and TKC 2.2.a. The three DSE isolates were able to grow at high acidity levels $(\mathrm{pH} 3, \mathrm{pH} \mathrm{4}$, and $\mathrm{pH} 5)$ as well as $\mathrm{Fe}$ concentrations of $500 \mathrm{ppm}$ and $1,000 \mathrm{ppm}$. All isolates were grown on Potato Dextrose Agar (PDA) medium at $25^{\circ} \mathrm{C}$.

\section{Preparation of Pyricularia oryzae Isolates}

Rice leaf samples were obtained from KP Muara ICRR infected with $P$. oryzae. The single spore isolation of $P$. oryzae refers to the method of Milati et al. (2016) with the aid of a microscope, then cultured on water agar media. The germinated spores were transferred to PDA and incubated for seven days. The mycelium was transferred to oatmeal agar (OMA). On day $10^{\text {th }}$, the mycelium on the surface of OMA was rubbed with a sterile brush dipped in sterile distilled water containing Streptomycin sulfate. After scrubbing, OMA was incubated for $2 \times 24$ hours in an incubator equipped with a 10 watt light lamp. $P$. oryzae spores are black in OMA. To collect the spores, OMA media was given a sterile distilled water solution plus Tween 20 (0.01 $\mathrm{ml} \mathrm{L}^{-1}$ ), rubbing the surface with a sterile brush. The spore suspension was put into a sterile bottle and ready to be inoculated.

\section{The Growth rate of Dark Septate Endophytes and Pyricularia oryzae}

This activity measures and observes the growth rate of DSE and Po colonies. DSE isolates (APDS 3.2; 4.1 BTG; and TKC 2.2.a) and rice blast pathogens ( $P$. oryzae) were grown on PDA media in Petri dishes. Isolates were incubated at room temperature and exposed to adequate lighting. The vertical and horizontal growth of the colonies was measured daily until the fungal colonies fulfilled the Petri dishes or the increase in colony diameter stops (Elfina et al., 2013).

\section{Dark Septate Endophytes Antagonism Test against Pyricularia oryzae}

The antagonism test used a dual culture method using PDA media in a Petri dish with a $9 \mathrm{~cm}$ diameter. The $P$. oryzae was planted five days earlier than the DSE fungi. Each fungus was placed opposite to each other at a distance of $3 \mathrm{~cm}$. The treatments were 
repeated three times and incubated for seven days. Observations were made on the presence or absence of an inhibition zone. The formula used to calculate inhibition (\%) was:

$$
E=\frac{x-y}{x} .100 \%
$$

Where: $\mathrm{E}=$ efficacy (\% inhibition), $\mathrm{x}=P$. oryzae growth area as a control $(\mathrm{cm}), \mathrm{y}=P$. oryzae growth area with DSE $(\mathrm{cm})$.

\section{Chitinase Qualitative Test}

The qualitative test for chitinase refers to Muharni (2009) method. DSE isolates were grown on solid chitin media and incubated for up to six days at room temperature. The clear zone formed can be observed after the addition of $0.3 \%$ Congo red, then rinsed with $0.1 \% \mathrm{NaCl}$. The clear zone is the result of the degradation of chitin into $\mathrm{N}$-acetyl-D-glucosamine monomers.

\section{Dark Septate Endophytes Inoculum and Inoculation Preparation}

DSEs inoculum preparation refers to the method of Andrade-linares et al. (2011). DSE isolates were grown on liquid Potato Dextrose Broth media for two weeks. The seeds of cv Inpara 2 were soaked in hot water $\left(50{ }^{\circ} \mathrm{C}\right)$ for 20 minutes, then surface sterilized with $3 \% \mathrm{NaOCl}$ (for 1 minute), followed with $70 \%$ alcohol (for 1 minute), and rinsed with sterile water two times (Sucipto et al., 2015). Rice seeds were immersed in DSE culture $(10 \% \mathrm{v} / \mathrm{w})$ with a density of $1 \times 10^{5}$ propagules $\mathrm{ml}^{-1}$ for 48 hours. Rice seeds were planted in a nursery medium using soil that has been sterilized twice. After 14 days, the plant height, root length, wet weight, and dry weight were measured for ten plant samples for each DSE treatment as well as of control rice plants.

\section{Dark Septate Endophytes Viability}

The DSEs viability was measured by immersion on PDA media and incubated for 7 days. This test was aimed to see the viability of DSE inoculum which would be inoculated on rice seeds.

\section{Detection of Dark Septate Endophytes Colonization in Rice Plants}

Colonization by the DSEs was carried out in the nursery phase. The detection method used a staining technique, which refers to Zhang et al. (2011). Root samples were cleaned and cut $\pm 2 \mathrm{~cm}$. The roots were soaked in a $10 \% \mathrm{KOH}$ solution at $90{ }^{\circ} \mathrm{C}$ in a water bath for 90 minutes. $\mathrm{KOH}$ was removed, and the roots were rinsed using distilled water. The roots were immersed in a $1 \mathrm{~N} \mathrm{HCl}$ solution for 24 hours, then the samples were stained with fuchsine acid for 20-30 minutes. The stained roots were stored in a $50 \%$ glycerol solution, then observed under a light microscope with a magnification of 400x.

\section{Data Analysis}

Data were analyzed using ANOVA with SAS 9.1. When the $F$ test showed significantly different, treatments were compared using Tukey test at the 95\% significant level.

\section{RESULTS AND DISCUSSION}

\section{Dark Septate Endophytes Growth Rate}

APDS 3.2 had the fastest colony growth than other DSE and filled the Petri dishes three days after incubation (DAI), while 4.1 BTG and TKC 2.2.a at 7 DAls. The fastest growth of APDS 3.2 colonies occurred at 1 DAl, $4.1 \mathrm{BTG}$ at $5 \mathrm{DAl}$, and TKC 2.2.a at $3 \mathrm{DAI}$ (Table 1). After $7 \mathrm{DAl}$, the APDS 3.2 color 
changes from white to black (Figure 1). The growth of fungal colonies was determined precisely by measuring the colony diameter as an estimator of fungal growth. Colony diameter is a good choice, given the good correlation between colony diameter and biomass dry weight (Gougouli \& Koutsoumanis, 2013).

Table 1. The growth rate of dark septate endophytes fungi

\begin{tabular}{|c|c|c|c|c|c|c|}
\hline \multirow[b]{3}{*}{ Days to- } & \multicolumn{6}{|c|}{ Growth rate of dark septate endophytes fungi } \\
\hline & \multicolumn{2}{|c|}{ APDS 3.2} & \multicolumn{2}{|c|}{$4.1 \mathrm{BTG}$} & \multicolumn{2}{|c|}{ TKC 2.2.a } \\
\hline & $\begin{array}{c}\text { Average } \\
\text { diameter } \\
(\mathrm{cm})\end{array}$ & $\begin{array}{c}\text { Difference in } \\
\text { growth per } \\
\text { day }\end{array}$ & $\begin{array}{l}\text { Average } \\
\text { diameter } \\
(\mathrm{cm}) \\
\end{array}$ & $\begin{array}{c}\text { Difference in } \\
\text { growth per } \\
\text { day }\end{array}$ & $\begin{array}{c}\text { Average } \\
\text { diameter } \\
(\mathrm{cm}) \\
\end{array}$ & $\begin{array}{c}\text { Difference } \\
\text { in growth } \\
\text { per day }\end{array}$ \\
\hline 1 & 4.20 & 4.20 & 1.35 & 1.35 & 1.31 & 1.31 \\
\hline 2 & 6.13 & 1.93 & 2.45 & 1.10 & 2.62 & 1.31 \\
\hline 3 & 9.00 & 2.87 & 4.06 & 1.61 & 5.10 & 2.48 \\
\hline 4 & - & & 5.71 & 1.64 & 6.24 & 1.14 \\
\hline 5 & - & & 7.38 & 1.67 & 7.40 & 1.16 \\
\hline 6 & - & & 8.72 & 1.48 & 8.39 & 0.99 \\
\hline 7 & - & & 9.00 & 0.28 & 9.00 & 0.61 \\
\hline
\end{tabular}

Colonies usually continue to grow within the same average radius until they encounter obstacles such as the tips of Petri dishes or other colonies (Nurbaya et al., 2010). Fungal growth may be greatly influenced by several physical factors such as temperature, $\mathrm{pH}$, light, aeration, pressure (Maharshi \& Thaker, 2012). In this research, Pyricularia oryzae has slow colony growth. The fastest growth of $P o$ colonies occurred in 1 DAl. Po colony growth was between $0.49-1.35 \mathrm{~cm} /$ day in the first ten days. Ten days later, the growth rate of $P o$ decreased with increasing incubation time ranging from 0.16 to $0.39 \mathrm{~cm} \mathrm{day}^{-1}$. Po colonies filled the Petri dishes at $20 \mathrm{DAl}$ (Table 2). Differences in fungal growth may be due to carbon utilization and nutrient consumption (Gayatonde et al., 2016).

Table 2. The growth rate of Pyricularia oryzae

\begin{tabular}{|c|c|c|c|c|c|c|c|c|c|c|}
\hline \multirow{2}{*}{ Parameter } & \multicolumn{10}{|c|}{ Growth rate of Pyricularia oryzae at the day of } \\
\hline & 1 & 2 & 3 & 4 & 5 & 6 & 7 & 8 & 9 & 10 \\
\hline $\begin{array}{l}\text { Average } \\
\text { diameter }(\mathrm{cm})\end{array}$ & 0 & 1.35 & 1.92 & 2.45 & 3.11 & 3.68 & 4.25 & 4.80 & 5.30 & 5.80 \\
\hline $\begin{array}{l}\text { Difference in } \\
\text { growth per day }\end{array}$ & 0 & 1.35 & 0.57 & 0.53 & 0.66 & 0.58 & 0.56 & 0.56 & 0.50 & 0.49 \\
\hline \multirow{2}{*}{ Parameter } & \multicolumn{10}{|c|}{ Growth date of Pyricularia oryzae at the day of } \\
\hline & 11 & 12 & 13 & 14 & 15 & 16 & 17 & 18 & 19 & 20 \\
\hline $\begin{array}{l}\text { Average } \\
\text { diameter }(\mathrm{cm})\end{array}$ & 6.18 & 6.56 & 6.94 & 7.11 & 7.27 & 7.93 & 8.15 & 8.38 & 8.61 & 9.00 \\
\hline $\begin{array}{l}\text { Difference in } \\
\text { growth per day }\end{array}$ & 0.38 & 0.38 & 0.39 & 0.16 & 0.16 & 0.66 & 0.27 & 0.23 & 0.23 & 0.39 \\
\hline
\end{tabular}




\section{Dark Septate Endophytes Antagonism Test against Pyricularia oryzae}

APDS 3.2 had a higher percentage of inhibition against Po than 4.1 BTG and TKC 2.2.a, but it was not statistically significant except for 5 and 6 DAl. The percentage of inhibition rised with increasing incubation days. Percentage of inhibition by APDS 3.2,
4.1 BTG, and TKC 2.2.a at 7 DAls was 43.75\%; 38.60\%; and 39.76\%, respectively (Table 3). The role of endophytic fungi in inhibiting the $P$. oryzae was in the form of competition for space and nutrition, reducing the production of toxins produced by pathogens so that they become less pathogenic to plants (Yulianti, 2013).

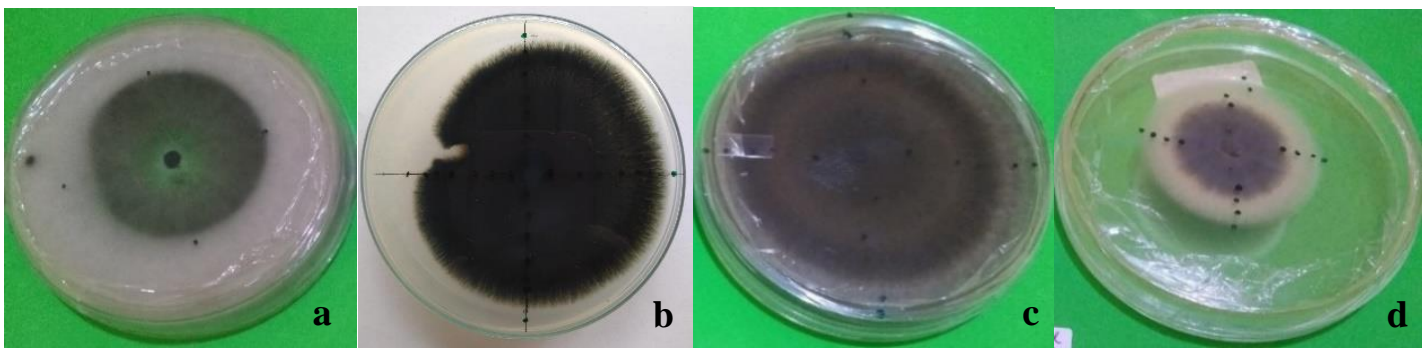

Figure 1. Fungal growth rate at 7 DAI: (a). APDS 3.2; (b). 4.1 BTG; (c). TKC 2.2.a; and (d). P. oryzae

Dual culture test results showed that DSE was able to inhibit Po. APDS 3.2 has a high-speed mycelial growth. APDS 3.2 at 7 DAl overgrowth Po. Meanwhile, 4.1 BTG withstanded the growth of $P O$ and TKC 2.2.a restricted the colony growth of $P o$ (Figure 2). APDS 3.2 had a high ability to inhibit the development of Po. The results of this research was in support with of Dalimunthe et al. (2019) that APDS 3.2 has high inhibiting capability. Dalimunthe et al. (2019) found that an isolate of DSEs that has faster colony growth than the pathogenic colony of $R$. microporus was able to suppress $R$. microporus. It appears that the development of the DSEs colony envelops and suppresses the development of the $R$. microporus colony.

Table 3. Percentage of dark septate endophytes inhibition against Pyricularia oryzae in dual culture tests.

\begin{tabular}{lccccccc}
\hline \multirow{2}{*}{ Treatment } & \multicolumn{7}{c}{ Percentage of Inhibition (\%) day of } \\
\cline { 2 - 8 } & 1 & 2 & 3 & 4 & 5 & 6 & 7 \\
\hline APDS 3.2 vs P. oryzae & $17.74 \mathrm{a}$ & $25.40 \mathrm{a}$ & $31.21 \mathrm{a}$ & $35.82 \mathrm{a}$ & $38.21 \mathrm{a}$ & $40.57 \mathrm{a}$ & $43.75 \mathrm{a}$ \\
4.1 BTG vs P. oryzae & $14.66 \mathrm{a}$ & $21.72 \mathrm{a}$ & $27.18 \mathrm{a}$ & $29.78 \mathrm{a}$ & $31.89 \mathrm{~b}$ & $33.97 \mathrm{~b}$ & $38.60 \mathrm{a}$ \\
TKC 2.2.a vs P. oryzae & $15.47 \mathrm{a}$ & $22.19 \mathrm{a}$ & $27.33 \mathrm{a}$ & $31.91 \mathrm{a}$ & $34.55 \mathrm{ab}$ & $36.78 \mathrm{ab}$ & $39.76 \mathrm{a}$ \\
\hline
\end{tabular}

The mechanisms of pathogens by biocontrol agents according to Agrios (2005); Atugala \& Deshappriya (2015) are by directly parasitizing pathogens, producing antibiotics (toxins), and by the ability to compete for space and nutrition.
Endophytes tended to slow the pathogen's growth compared to controls, possibly by producing antibiotics substances. In this study, the growth of pathogen (P. oryzae) was inhibited due to competition with DSEs. 


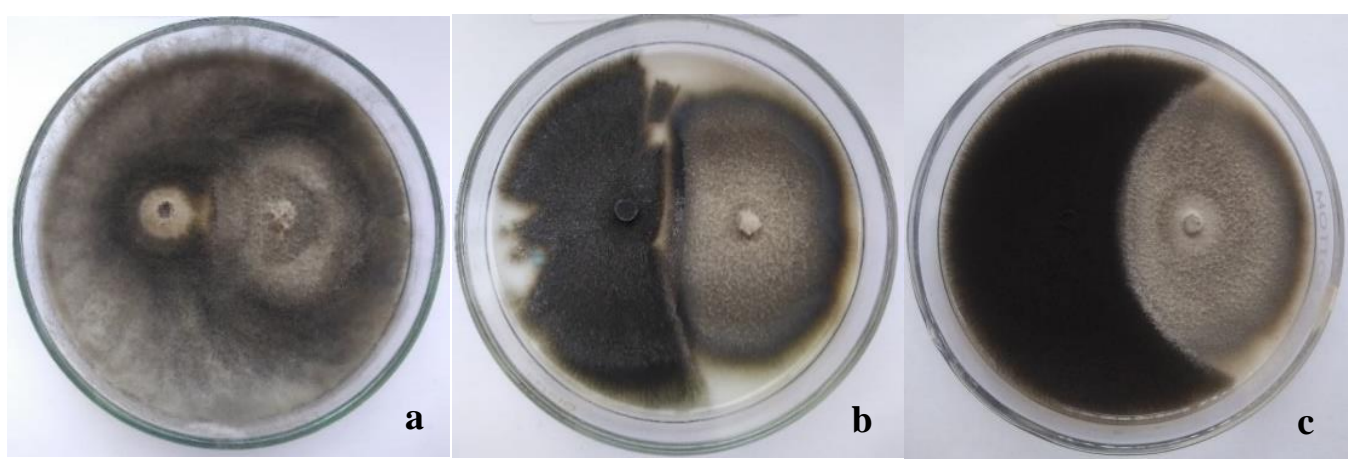

Figure 2. Inhibition of $P$. oryzae (left) by the DSE fungal (right) in a dual culture test at $7 \mathrm{DAl}$ : (a). APDS 3.2; (b). 4.1 BTG; and (c). TKC 2.2.a.

\section{Chitinase Qualitative Test}

The three DSE isolates had chitinase enzyme activity as can be seen from the clear zone produced around the fungal colonies. APDS 3.2 had a clear zone larger than 4.1 BTG and TKC 2.2.a (Figure 3). The chitinase enzyme is a hydrolytic enzyme that degrades chitin. Chitinase can act as an antifungal for biological control of pathogenic fungi (Fadhil et al., 2014). The three DSE isolates were able to degrade the cell walls of pathogenic fungi that have chitin components.

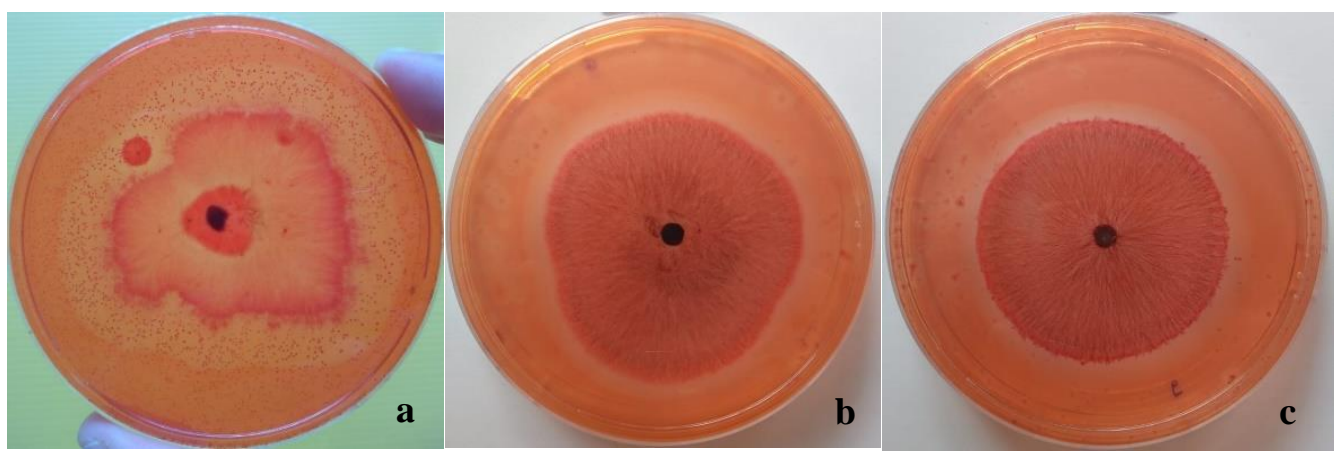

Figure 3. Chitinase test on DSE: (a). APDS 3.2; (b). 4.1 BTG; and (c). TKC 2.2.a.

\section{Dark Septate Endophytes Viability}

The DSE inoculum was tested on PDA medium for viability before application to rice seeds. The three DSE grew well from 1 DAl to $7 \mathrm{DAl}$, to fulfill the PDA media. This test showed that the DSEs inoculum had good viability (Figure 4). Viability has a positive correlation with the level of fungal infectivity (Prayogo \& Santoso, 2013). The same goes for bacteria, Bacillus sp. after being formulated, its viability and antagonistic ability are still maintained (Fakhruddin \& Nurcahyanti, 2020). 


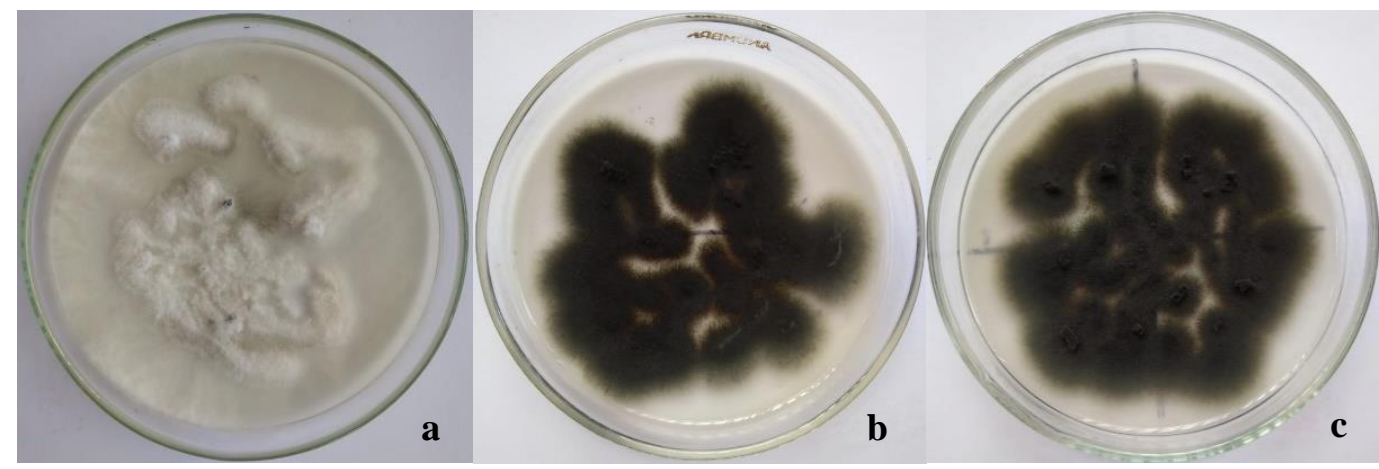

Figure 4. Dark Septate Endophytes viability: (a). APDS 3.2; (b). 4.1 BTG; and (c). TKC 2.2.a.

\section{Agronomic Parameters in the Nursery}

The height of rice plants inoculated with APDS 3.2 was relatively higher than the rice plants inoculated with TKC 2.2.a and 4.1 BTG at 1 and 2 weeks after sowing, although statistical analysis was not significantly different. However, the height of rice plants inoculated with DSE was significantly different from the control treatment. Likewise, the root length, wet weight, and plant dry weight in the APDS 3.2 treatment were relatively better than the other DSE treatments. All DSE fungi gave a significant effect compared to control on rice plants agronomic parameters in the nursery (Table 4). He et al., (2019) showed that DSE inoculation could increase plant biomass by increasing $\mathrm{N}$ and $\mathrm{P}$ elements absorption by plants. This absorption was consequently depleting these macronutrients in the soil.

Table 4. Average plant height, root length, wet weight and dry weight of rice plants in the nursery.

\begin{tabular}{|c|c|c|c|c|c|c|}
\hline \multirow{2}{*}{ No. } & \multirow{2}{*}{ Treatment } & \multicolumn{2}{|c|}{ Plant height $(\mathrm{cm})$} & \multirow{2}{*}{$\begin{array}{l}\text { Root length } \\
(\mathrm{cm})\end{array}$} & \multirow{2}{*}{$\begin{array}{l}\text { Plant wet } \\
\text { weight }(\mathrm{g})\end{array}$} & \multirow{2}{*}{$\begin{array}{l}\text { Plant dry weight } \\
\text { (g) }\end{array}$} \\
\hline & & 1 WAS & 2 WAS & & & \\
\hline 1 & APDS 3.2 & $15.90 \mathrm{a}$ & $30.80 \mathrm{a}$ & $10.96 \mathrm{a}$ & $0.160 \mathrm{a}$ & $0.125 a$ \\
\hline 2 & 4.1 BTG & $15.05 \mathrm{a}$ & $30.00 \mathrm{a}$ & $9.14 a b$ & $0.126 a$ & $0.119 a$ \\
\hline 3 & TKC 2.2.a & $15.60 \mathrm{a}$ & $30.15 a$ & $9.47 a b$ & $0.155 a$ & $0.119 a$ \\
\hline 4 & Kontrol & $13.32 b$ & $24.65 b$ & $7.80 \mathrm{~b}$ & $0.081 b$ & $0.097 \mathrm{a}$ \\
\hline
\end{tabular}

Before the rice plants transplanted into plastic buckets, it was seen that the rice plants inoculated with APDS 3.2 had better plant vigour than the other treatments in terms of plant height, root length, and number of rice roots (Figure 5). Endophytes can actively or passively trigger plant growth through various mechanisms. Endophytes are providing various metabolites enhancements for host plants fitness by increasing plant resistance to biotic and abiotic stresses and increasing plant growth (Sudha et al., 2016). 


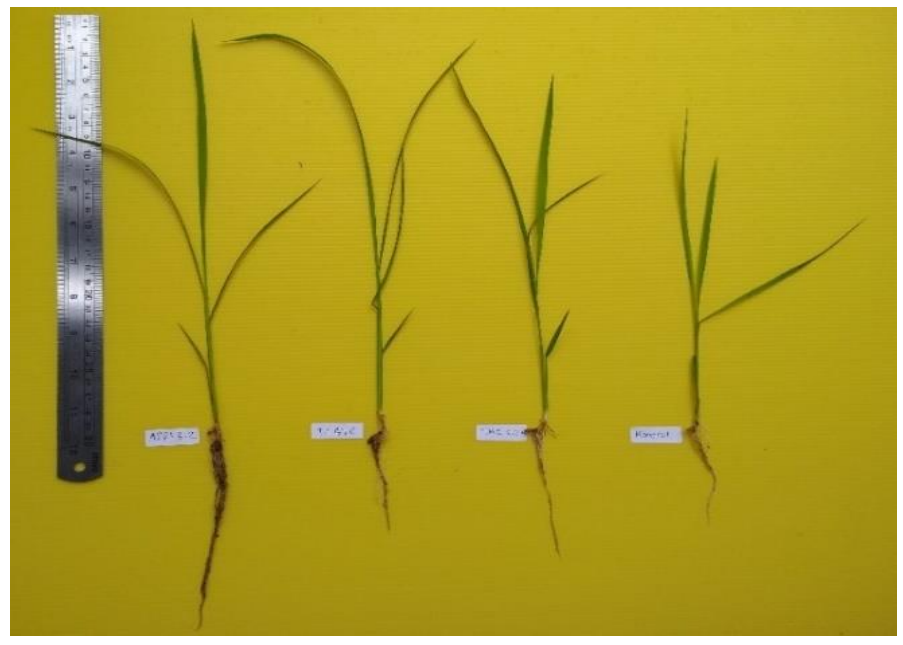

Figure 5. Growth of rice plants aged 2 weeks after sowing on DSEs and control treatments (left to right): APDS 3.2; 4,1 BTG; TKC 2.2.a; and control.

Endophytes fungi can stimulate plant canopy growth and have a higher wet weight than controls (Syarif et al., 2014). Vergara et al. (2018) stated that dark septate endophytes fungi could access carbon, nitrogen, and phosphorus from rhizospheres and deliver them to the host. In-plant tissue, endophytes will actively protect plants directly or indirectly. Directly through chemical activity produced against pathogens, while indirectly producing some gene regulation of plant resistance to pathogens and increasing plant vigour (Herre et al., 2007).

\section{Dark Septate Endophytes Colonization Detection on Rice Roots}

DSEs microscopic observations on rice roots shows fungal conidia, as shown in Figure 6. APDS 3.2 had hyaline and oval conidia. While 4.1 BTG and TKC 2.2.a had brown conidia with two septate and in the middle was slightly bent on one side, and both ends were tapered like a boomerang. According to (Surono \& Narisawa, 2018), DSE can colonize plant roots both intercellular and intracellularly without causing disease.

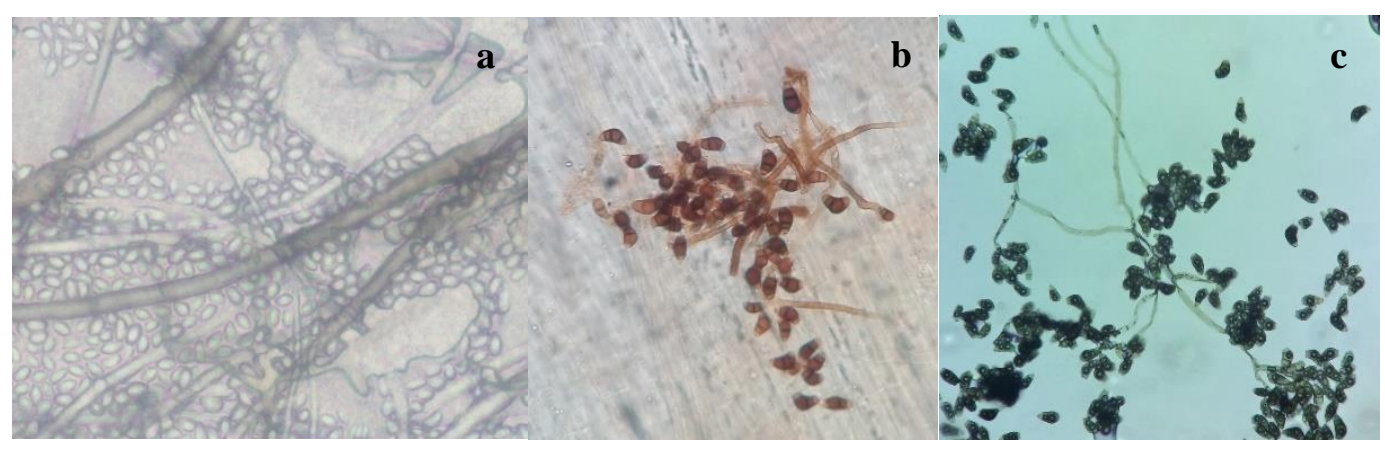

Figure 6. DSE colonization of rice roots at 400x magnification: (a). APDS 3.2; (b). 4.1 BTG; and (c). TKC 2.2.a

The highest DSEs colonization in rice roots in the nursery was found in the APDS
3.2 at $50.56 \%$, followed by TKC 2.2.a and 4.1 BTG (Table 5). The results of Khastini (2007) 
study showed that the colonization process of Aspergillus niger using the staining method and the GFP marker gene showed that the colonization process began with the penetration of hyphae into the root epidermal tissue, then an apresorium was formed followed by the formation of intercellular hyphae in the epidermis and root cortex and hyphal formation of swollen structures in the root cortex.

Table 5. Dark septate endophytes colonization of rice roots in the nursery phase

\begin{tabular}{rlc} 
No. & Treatment & Colonization (\%) \\
\hline 1 & APDS 3.2 & $50.56 \mathrm{a}$ \\
2 & 4.1 BTG & $40.00 \mathrm{a}$ \\
3 & TKC 2.2.a & $46.67 \mathrm{a}$ \\
4 & Kontrol & $0.00 \mathrm{~b}$ \\
\hline
\end{tabular}

Plant root tissue provides a conducive habitat for various microbial communities, including endophytes fungi (Bashir et al., 2016). Plant roots are heavily colonized by various endophytes fungi, especially the dark septate endophytes group (Knapp et al., 2012). The application of endophytes fungi bioformulation to seeds or aerial parts will be more effective than application in the rhizosphere. The microbes are in the plant tissue and will not face competition with other soil microbes, which generally occurs in the rhizosphere case microbes. Moreover, the benefits are directly transferred to the host plant in a closed system with minimal leakage of metabolites (Khare et al., 2018).

Several DSE isolates obtained from tropical environments can colonize and trigger two rice varieties' growth with and without stress (Santos et al., 2017). DSEs can increase host growth and nutrient uptake in several environmental conditions. Increased growth and increased nutritional status indicate better performance because of the results of DSEs colonization (Andrade-linares et al., 2011).

\section{CONCLUSION}

1. APDS 3.2 had the fastest colony growth than the other DSE, at three days after incubation (DAI) had filled the Petri dishes $(\mathrm{d}=9 \mathrm{~cm})$, while $4.1 \mathrm{BTG}$ and TKC 2.2.a at seven DAI. Pyricularia oryzae had slow colony growth and required $20 \mathrm{DAl}$.

2. APDS 3.2 had a percentage of inhibition against $P$. oryzae of $43.75 \%$ higher than 4.1 BTG (38.60\%) and TKC 2.2.a (39.76\%).

3. The three DSE isolates had chitinase enzyme activity and had good viability.

4. The rice plants inoculated by APDS 3.2 had a relatively higher plant at height, root length, wet weight and dry weight than those inoculated by TKC 2.2.a and 4.1 BTG.

5. The highest DSE colonization in rice roots in nurseries found in rice plants inoculated with APDS 3.2 at $50.56 \%$, followed by TKC 2.2.a (46.67\%) and 4.1 BTG (40\%).

6. DSEs fungi has the potential to suppress rice blast pathogens by improving the health of rice plants, especially APDS 3.2 under in-vitro condition.

\section{ACKNOWLEDGEMENTS}

Many thanks to Indonesian Agency for Agricultural Research and Development (IAARD), Ministry of Agriculture for the 
scholarship during my postgraduate education at Phytopathology, IPB University.

This work was partly supported by the Indonesian Ministry of Research and Technology for INSINAS 2019 Grant Number 10/INS-1 (to Surono). The Funding source had no role in study design; in the collection, analysis, and the writing of the report; and in the decision to submit the article for publication.

The author would like to thank Ir. Yadi Suryadi, MSc for guidance on research in the field and Dr. Dwi Ningsih Susilowati, MSi for permission to conduct research in the ICABIOGRAD laboratory.

\section{REFERENCES}

Agrios, G. N. (2005). Plant pathology. In Elsevier Academic Press (Fifth). Elsevier Academic Press. https://doi.org/10.1016/C2009-002037-6

Ahn, S.-N., Kim, Y.-K., Hong, H.-C., Han, S.-S., Soo-Jin Kwon1, H.-, Choi, C., Moon, H.P., \& McCouch, S. R. (2000). Molecular mapping of a new gene for resistance to rice blast (Pyricularia grisea Sacc.). Euphytica, 116, 17-22. https://doi.org/DOI: 10.1023/A:1004045812357

Amaria, W., Harni, R., \& Samsudin. (2015). Evaluasi jamur antagonis dalam menghambat pertumbuhan Rigidoporus microporus penyebab penyakit jamur akar putih pada tanaman karet. Jurnal Tanaman Industri Dan Penyegar, 2(1), 51-60. https://doi.org/10.21082/jtidp.v2n1.2 015.p51-60

Andrade-linares, D. R., Grosch, R., Franken, P., Rexer, K. H., Kost, G., Restrepo, S., de Garcia, M. C. C., \& Maximova, E. (2011). Colonization of roots of cultivated Solanum lycopersicum by dark septate and other ascomycetous endophytes. Mycologia, 103(4), 710-
721. https://doi.org/10.3852/10-329

Atugala, D. M., \& Deshappriya, N. (2015). Effect of endophytic fungi on plant growth and blast disease incidence of two traditional rice varieties. Journal of the National Science Foundation of Sri Lanka, 43(2), 173-187. https://doi.org/10.4038/jnsfsr.v43i2.7 945

Bashir, O., Khan, K., Hakeem, K. R., Mir, N. A., Rather, G. H., \& Mohiuddin, R. (2016). Soil microbes diversity and root exudates as important aspects of rhizosphere ecosystem. In K. R. Hakeem \& M. S. Akhtar (Eds.), Plant, Soil and Microbes: Volume 2: Mechanisms and Molecular Interactions (Issue January, pp. 337357). Springer International Publishing Switzerland. https://doi.org/10.1007/978-3-31929573-2

Dalimunthe, C. I., Soekarno, B. P., Munif, A., \& Surono, S. (2019). Seleksi dan uji potensi cendawan Dark Septate Endophyte sebagai agensia hayati penyakit jamur akar putih (Rigidoporus microporus) pada tanaman karet. Jurnal Penelitian Karet, 37(1), 11-20. https://doi.org/10.22302/ppk.jpk.v37i 1.624

Dewi, I. M., Cholil, A., \& Muhibuddin, A. (2013). Hubungan karakteristik jaringan daun dengan tingkat serangan penyakit blas daun (Pyricularia oryzae Cav.) pada beberapa genotipe padi (Oryza sativa L.). Jurnal HPT, 1(2), 10-17. https://www.researchgate.net/public ation $/ 265164278$

Elfina, Y. S., Dewi, R., \& Ibrahim, R. (2013). $\mathrm{Uji}$ pelet biofungisida yang mengandung beberapa isolat Trichoderma sp. lokal Riau terhadap penyakit yang disebabkan oleh Ganoderma boninense pat. secara in- 
vitro. Prosiding Seminar Nasional "Peranan Teknologi Dan Kelembagaan Pertanian Dalam Mewujudkan Pembangunan Pertanian Yang Tangguh Dan Berkelanjutan"., November, 111-124. http://eksakta.ppj.unp.ac.id

Fadhil, L., Kadim, A., \& Aljebory, A. M. (2014). Production of Chitinase by Serratia marcescens from Soil and Its Antifungal Activity. Journal of Natural Sciences Research Www, 4(8), 80-86. https://www.researchgate.net/public ation/284550192

Fakhruddin, D. K., \& Nurcahyanti, S. D. (2020). Viabilitas Bacillus sp. sebagai agen antagonis patogen tanaman dalam formulasi berbahan dasar tepung. Jurnal Pengendalian Hayati, 3(1), 29-37. https://doi.org/10.19184/jph.v3i1.17 151

Fukuta, Y., Koga, I., Ung, T., Sathya, K., Kawasaki-Tanaka, A., Koide, Y., Kobayashi, N., Obara, M., Yadana, H., \& Hayashi, N. (2014). Pathogenicity of rice blast (Pyricularia oryzae Cavara) isolates from Cambodia. JARQ, 48(2), 155-166.

Gayatonde, V., Mahadevu, P., \& Vennela, P. R. (2016). Study of suitable culture media and other abiotic factors for the growth and sporulation of Magnaporthe oryzae. Ecology, Environment and Conservation, 22(2), 297-301.

Gougouli, M., \& Koutsoumanis, K. (2013). Primary models for fungal growth. In P. D (Ed.), Predictive Mycology (1st ed., Issue January 2013, pp. 63-130). Nova Science.

https://www.researchgate.net/public ation/280729007

Handayani, D. (2017). Karakteristik cendawan dark septate endophyte (DSE) pada akar tanaman jagung dan padi. Eksakta, 18(1), 61-68. http://eksakta.ppj.unp.ac.id

He, C., Wang, W., \& Hou, J. (2019). Characterization of dark septate endophytic fungi and improve the performance of liquorice under organic residue treatment. Frontiers in Microbiology, 10(June), 1-14. https://doi.org/10.3389/fmicb.2019.0 1364

Herre, E. A., Mejía, L. C., Kyllo, D. A., Rojas, E. I., Maynard, Z., Butler, A., \& Van Bael, S. A. (2007). Ecological implications of anti-pathogen effects of tropical endophytes and mycorrhizae. Ecology, 88(3), 550-558. https://doi.org/10.1890/05-1606

Hosseini-moghaddam, M. S., \& Soltani, J. (2013). An investigation on the effects of photoperiod, aging and culture media on vegetative growth and sporulation of rice blast pathogen Pyricularia oryzae. Progress in Biological Sciences, 3(2), 135-143.

Khare, E., Mishra, J., \& Arora, N. K. (2018). Multifaceted interactions between endophytes and plant: developments and prospects. Frontiers in Microbiology, 9(Nov), 1-12. https://doi.org/10.3389/fmicb.2018.0 2732

Khastini, R. O. (2007). Isolasi, penapisan, respon tumbuh dan proses kolonisasi cendawan mutualistik akar (Tesis). Institut Pertanian Bogor.

Knapp, D. G., Pintye, A., \& Kovács, G. M. (2012). The dark side is not fastidious dark septate endophytic fungi of native and invasive plants of semiarid sandy areas. PLOS ONE, 7(2), 1-8. https://doi.org/10.1371/journal.pone .0032570

Maharshi, A. R., \& Thaker, V. S. (2012). Growth and development of plant pathogenic fungi in define media. European Journal of Experimental Biology, 2(1), 44-54. 
www.pelagiaresearchlibrary.com Pelagia

Milati, L. N., Nasution, A., \& Sudir. (2016). Metode identifikasi Ras Pyricularia grisea Sacc. penyebab penyakit blas pada tanaman padi. In $\mathrm{S}$. et al. Abdulrachman (Ed.), Prosiding Temu Teknologi Padi 2015 (pp. 429-436). Balai Besar Penelitian Tanaman Padi.

Muharni. (2009). Isolasi dan identifikasi bakteri penghasil kitinase dari sumber air panas danau Ranau Sumatera Selatan. Jurnal Penelitian Sains, 9(D), 12-15.

Nurbaya, Kuswinanti, T., Baharuddin, Rosmana, A., \& Millang, S. (2010). Uji kecepatan pertumbuhan Fusarium spp. pada media organik dan media sintesis. Jurnal Bionature, 15(1), 4553.

Pandya, U., \& Saraf, M. (2010). Application of fungi as a biocontrol agent and their biofertilizer potential in agriculture. Research Journal of Biotechnology, 5(3), 5-9. https://www.researchgate.net/public ation/292574989\%0AApplication

Prayogo, Y., \& Santoso, T. (2013). Viabilitas dan infektivitas formulasi cendawan entomopatogen Lecanicillium lecanii sebagai biopestisida pengendalian telur kepik coklat Riptortus linearis. Penelitian Pertanian Tanaman Pangan, 32(1), 57-66.

Santos, S. G. dos, Silva, P. R. A. da, Garcia, A. C., Zilli, J. É., \& Berbara, R. L. L. (2017). Dark septate endophyte decreases stress on rice plants. Brazilian Journal of Microbiology, 48(2), 333-341. https://doi.org/10.1016/j.bjm.2016.0 9.018

Sesma, A., \& Osbourn, A. E. (2004). The rice leaf blast pathogen undergoes developmental processes typical of root-infecting fungi. Nature, 431(7008), 582-586. https://doi.org/10.1038/nature02880

Siagian, A. (2016). Gejala anatomi dan kerusakan penyakit blas (Pyricularia oryzae) pada tanaman padi. Institut Pertanian Bogor.

Sucipto, I., Munif, A., Suryadi, Y., \& Tondok, E. T. (2015). Eksplorasi cendawan endofit asal padi sawah sebagai agens pengendali penyakit blas pada padi sawah. Jurnal Fitopatologi Indonesia, 11(6), 211-218. https://doi.org/10.14692/jfi.11.6.211

Sudha, V., Govindaraj, R., Baskar, K., AlDhabi, N. A., \& Duraipandiyan, V. (2016). Biological properties of endophytic Fungi. Brazilian Archives of Biology and Technology, 59, 1-7. https://doi.org/10.1590/1678-43242016150436

Sudir, Nasution, A., Santoso, \& Nuryanto, B. (2014). Penyakit blas Pyricularia grisea pada tanaman padi dan strategi pengendaliannya. Iptek Tanaman Pangan, 9(2), 85-96.

Suganda, T., Yulia, E., Widiantini, F., \& Hersanti, H. (2016). Intensitas penyakit blas (Pyricularia oryzae Cav.) pada padi varietas Ciherang di lokasi endemik dan pengaruhnya terhadap kehilangan hasil. Agrikultura, 27(3), 154-159.

https://doi.org/10.24198/agrikultura. v27i3.10878

Surono, \& Narisawa, K. (2018). The inhibitory role of dark septate endophytic fungus Phialocephala fortinii against Fusarium disease on the Asparagus officinalis growth in organic source conditions. Biological Control, 121, 159-167. https://doi.org/10.1016/j.biocontrol. 2018.02.017

Syarif, A. S., Nurjayadi, M. Y., \& Munif, A. (2014). Isolasi cendawan endofit dari tanaman padi dan potensinya sebagai pemacu pertumbuhan tanaman. In N. 
Mubin, M. G. Pradana, Suryadi, M. Y. Nurjayadi, \& D. Sukaryana (Eds.), Prosiding Seminar Nasional Perlindungan Tanaman II (pp. 132138). Pusat Kajian Pengendalian Hama Terpadu.

Vergara, C., Araujo, K. E. C., Urquiaga, S., Santa-catarina, C., Schultz, N., Araujo, E. da S., Balieiro, F. de C., Xavier, G. R., \& Zilli, J. E. (2018). Dark septate endophytic fungi increase green manure- $15 \mathrm{~N}$ recovery efficiency, $\mathrm{N}$ contents, and micronutrients in rice grains. Frontier in Plant Science, 9, 111.

https://doi.org/10.3389/fpls.2018.00

613

Yulianti, T. (2013). Pemanfaatan endofit sebagai agensia pengendali hayati hama dan penyakit tanaman. Buletin Tanaman Tembakau, Serat \& Minyak Industri, 5(1), 40-49. https://doi.org/10.21082/bultas.v5n1 .2013.40-49

Zarandi, M. E., Bonjar, G. H. S., Dehkaei, F. P., Moosavi, S. A. A., Farokhi, P. R., \& Aghighi, S. (2009). Biological control of rice blast (Magnaporthe oryzae) by use of Streptomyces sindeneusis isolate 263 in greenhouse. American Journal of Applied Sciences, 6(1), 194199.

Zhang, H., Wu, Z., Wang, C., Li, Y., \& Xu, J. (2014). Germination and infectivity of microconidia in the rice blast fungus Magnaporthe oryzae. Nature Communications, 5, 1-9. https://doi.org/10.1038/ncomms551 8

Zhang, Y., Li, T., \& Zhao, Z. (2011). The colonization of plants by dark septate endophytes (DSE) in the valley-type savanna of Yunnan, southwest China. African Journal of Microbiology Research, 5(31), 5540-5547. https://doi.org/10.5897/ajmr10.389 